\title{
BRANDING AS AN EFFECTIVE MARKETING STRATEGY FOR THE COMPETITIVENESS OF THE DAIRY INDUSTRY
}

\author{
Olha Kovalchuk ${ }^{1}$
}

\begin{abstract}
The purpose of the paper is to justify the theoretical concept, to identify the main trends and develop practical recommendations for the use of branding by dairy companies to increase their competitiveness. Methodology. To achieve results, it is necessary to develop the theoretical foundations of branding; to consider the current state and trends of the dairy market in Ukraine; to analyze the experience of other countries using branding; determine the role of branding in the marketing strategy of the dairy industry. Results. The article proves the growing role of branding in ensuring the competitiveness of enterprises. The content of the concept of brand and branding as a component of marketing activities is revealed. The expediency of forming a premium pricing strategy is justfied. Peculiarities of branding on the market of dairy products of Ukraine are highlighted. The main trends in the development of the range of dairy products are studied: healthy nutrition, growth of the "vegetable milk" sector and lactose-free products. The target segment of consumers and its features, the main stages of the advertising campaign in promoting dairy products on the market are determined. Practical implications. Creating new brands of dairy products and distributing them to the market through branding is an effective method of ensuring the competitiveness of dairy products, but Ukrainian producers do not know how to use it successfully. This is due to the fact that competition in the field of dairy products is very high, and therefore the use of various measures to improve product quality and price measures of competition are quite limited. Therefore, non-price factors of dairy product competitiveness and non-price factors of competition come to the fore. Branding helps to reduce the cost of services to promote dairy products on the market and increase the commercial effect. The subject of research is a set of theoretical, methodological aspects of the organization and application of branding dairy companies in order to increase their competitiveness. Branding as an effective tool of communication policy of enterprises will ensure and then increase the competitiveness of poultry products through its personalized positioning and promotion.
\end{abstract}

Key words: brand, branding, competitiveness, marketing strategy, loyalty, dairy market.

JEL Classification: M31, L66

\section{Introduction}

In conditions of increased competition, the marketing activities of enterprises should offer programs and activities, which will distinguish the company and its products against the background of similar products. The main factors for the successful existence of the company are longterm relationships with consumers, their trust, loyalty, intangible assets. As a result, the concept of branding is becoming increasingly important and helps to ensure the competitiveness of products. In the dairy market, branding has its own specifics, so it requires additional research. Thus, the study of branding as part of a complex of marketing and promotion and as a condition for ensuring the competitiveness of the enterprise in the dairy market is relevant.

In the marketing activities of modern enterprises there are several basic elements that form a complex of marketing (product, price, distribution and promotion). The ratio of these elements for each company is exceptional, and depends on the scale of activity, the degree of market coverage, competitive status, and the chosen strategy. Among the components of the marketing complex a special place is occupied by branding, because as the initial component of marketing product policy, also performs a secondary but very important function in the communications system, actively influences the formation of pricing and distribution policy.

\footnotetext{
Corresponding author:

${ }^{1}$ Zhytomyr Polytechnic State University, Ukraine.

E-mail: antonyy2703@gmail.com

ORCID: https://orcid.org/0000-0003-4147-7844
} 
Branding is the activity of creating a lasting commitment to the product based on the joint impact on the consumer of advertising appeals, brand, packaging, ROS-materials, promotions and other elements of advertising, combined with a certain idea and design that distinguish the product from competitors and create its image (Rays, 2003). Branding is realized by influencing the consumer by choosing a trademark, packaging (product), a set of advertising appeals. All this is designed to distinguish a particular brand from competitors, creating its most attractive image (Shcho take brend i brendynh). Brand management helps to promote and manage the latest technologies in the markets effectively. Companies try to use it when they understand that their brands are not created by them, but by consumers. Because brands exist in the minds of consumers, and without managing their emotional attachment, they are and will be only goods, services and businesses, not brands (Pertsiya, Mamleeva, 2007).

Using the concept of branding, companies create sustainable competitive advantages for their own brands, which helps to increase customer loyalty. That is why it is important to achieve brand individuality and develop technologies to attract consumers to the brand.

\section{Presentation of the main research material.}

An important role in ensuring food security of the state is played by the dairy complex, which includes a complex of agricultural and industrial enterprises engaged in the production, processing and marketing of dairy products. The dairy industry is socially oriented and a priority in the agricultural economy. It provides the country's population with food and needs constant regulation and support from the state, for the development and dissemination of positive trends.

The world leaders in dairy production are the EU, India and the United States, which together produce half of the world's milk. China produces only $5 \%$ and shares 4th and 5th places with Pakistan. Ukraine is in the top ten largest producing countries with a volume of 10.6 million tons and has a share of $1.3 \%$ in world production. Forecasts for an increase in production and consumption of dairy products are based on: income growth, expansion of the middle class, stable demand for animal protein.

The dairy industry, which includes the butter, cheese, dairy canning sub-sectors, as well as the production of whole milk products, is one of the leading industries, which in total accounts for 9\% of the entire processing industry of Ukraine. The development of the dairy industry directly depends on the state of dairy farming, which in recent years has shown a negative direction.

The company's brand is one of the non-price means of product competitiveness management, the main task of which is to form the image of consumer properties, price position, level of service and more.

Most manufacturers neglect branding as a major component of the process of managing the competitiveness of enterprise products (Nahorniak, 2008). However, this is a wrong approach, because the brand is one of the competitive advantages of the company in the long run and, accordingly, a factor in the formation of competitiveness.

Branding allows you:

- to maintain the planned sales volume in a particular market and implement a long-term program to create and consolidate the image of the brand in the minds of consumers;

- to ensure the growth of profits by increasing the range of products and information about their special qualities;

- to disseminate information about the culture of the country, region, city where the product is manufactured in advertisements,taking into account the needs of consumers for whom it is intended, as well as the characteristics of the territory where it is sold (Malinka, 2006).

Using the concept of branding, companies create sustainable competitive advantages for their brands, which help to increase consumer loyalty. Therefore, it is important to achieve brand individuality and develop technologies to attract consumers to the brand. According to A. Wheeler, building a brand identity is a promise, the main idea, reputation and expectations that are created in the human mind regarding the individuality of a product or company. It is a powerful intangible asset that creates emotional connections between the producer (seller) and the consumer (Wheeler, 2004).

A brand is one of the most effective means of improving the efficiency of the technical level of production, a tool for updating production, bringing its technology to the modern level, a means of significantly improving the quality of products or services. This sets the necessary range of goods or services that the consumer needs. 
The product under an individual brand must be unique. The success of a brand is influenced by factors such as advertising costs, product uniqueness, packaging quality, the conceptual idea of a new brand and the degree of customer satisfaction. Thanks to the brand identity strategy, it is possible to clearly adjust the brand to a specific market niche and target audience.

Sometimes, brands that enter the international market use a different name. However, each individual brand requires great effort and investment, which reduces the overall profitability. The success of one brand is not transferred to others, so such a strategy can only be considered as protective (Shamanska, Savetin, Marchuk, 2013).

Nowadays, strong brands become an unlimited condition for achieving sustainable and longterm market success of the enterprise through opportunities that determine a higher price without changing sales; ensuring more stable demand; creating barriers to entry for new competitors. Accordingly, lowering the cost of capital reduction, recruitment and support costs, active sales and customer loyalty lead to lower sales costs and more unfavorable conditions for suppliers. In addition, the effect of scale is achieved by increasing sales. The combination of these factors leads to an increase in the value of companies (Shamanska, Savetin, Marchuk, 2013).

When a company uses its own brand as an asset, it can set a premium price on it, make more profit and enjoy all the other benefits, which leads to one thing - the high value of the brand. The advantages of this method are:

- setting a higher price compared to competitors. Strong brands have the opportunity to set a higher price for their products relative to a competing brand. According to recent research, we have found that consumers who are loyal to a brand can pay for them a higher price than the usual price, regardless of product category;

- the stronger the brand, the greater the probability of reimbursement for the development and release of new products. A strong brand allows you to encourage consumers to a new product. The sooner consumers try a new product, the faster the cost of developing it will pay off. The stronger the brand, the faster consumers buy new products;

- loyal customers agree to pay a premium price for the brand, which increases its profitability per customer. The longer a brand manages to retain a consumer, the more profitable it becomes, and then the consumer is willing to pay a premium price for a product under its name;

- premium prices provide a high level of control over the distribution channel. When a well-known brand is sold at a high price, the members of the distribution channel receive quite high profits without competing with each other;

- profitable opportunities for collective branding appear. However, it should be noted that it is not necessary to increase the brand's portfolio just for the sake of profit;

- the company has the opportunity to offer its brand to different segments of consumers and get the whole category without any reduction in the value of the brand (Zvarevich, 2012).

The dairy industry, which includes butter, cheese, milk canning sub-sectors, as well as the production of whole milk, is one of the leading industries, which in total accounts for $9 \%$ of the total processing industry of Ukraine. The development of the dairy industry directly depends on the state of dairy farming, which in recent years has shown a negative direction.

The modern market of dairy products is constantly growing, competition is constantly increasing. The reason for this is the endless increase in production by various enterprises and gradual changes in the form of consumption. The competition in the market is quite strong, so production with the latest technologies and modern promotion systems will have an advantage. Consumers are becoming more picky about products. Therefore, it is an urgent task for dairy companies to create an effective marketing strategy and promotion tools aimed at developing and promoting dairy products on the market, which would be effective in the long run.

Every day the population is a consumer of dairy products. Regular consumers of dairy products are children and the elderly. It is important to identify the model of consumer behavior in the dairy market, which will certainly help to choose the optimal branding strategy.

According to the scientists' researches, the Ukrainian consumer perceives traditional dairy products (milk, sour cream, kefir) as a basic food, while the modern fermented milk category (yogurts, curds with fillers) is considered to some extent as a "luxury" (Demchuk, 2016).

According to the survey, an important factor for the consumer is the quality of products. The population is accustomed to believe that the products are made in accordance with state 
standards, indicating the use of only natural ingredients that guarantee food safety and are guaranteed quality (Demchuk, 2016). It should be noted that consumers who focus on specific brands are psychologically confident in the quality of such products.

Currently, the topic of healthy eating is developing in the community, according to which the demand is increasing and the transition from regular to vegetable milk is gradually taking place. This directly affects the industry and the competitive position of domestic goods on the world market, as in our country not everyone adheres to the conditions and quality standards that are regulated in the European market. A large number of domestic products are not produced outside the country, as they do not comply with certain market laws. However, this is not the only reason that stops domestic products from entering foreign markets. In order to have a competitive position with global manufacturers, it is necessary to upgrade and modernize production facilities. Also, companies that want to enter the EU area with their products must be included in third world countries that have a permit to trade with the EU.

Today we can identify the main global trends in the range of dairy products:

1. Healthy eating. In the structure of domestic consumption there is a tendency to switch to a healthy and high-quality diet, which increases the popularity of products without the use of preservatives and other additives. Thus, in the dairy market there is a strong tendency to choose natural products, so a successful brand must ensure maximum naturality of the product.

2. Increasing demand for lactose-free products. In recent years, demand for lactose-free products has grown significantly. The reason for this is that a large number of people have lactose intolerance. In particular, in the United States such people are more than 5\%, in Europe - 10\%, and in China 90\% of the population are lactose intolerant. Lactosefree dairy products stimulate sales in these markets, and the supply of such products is becoming increasingly diversified. The United States produces $29 \%$ of all lactose-free foods consumed worldwide. The average annual growth of such a market is estimated at 7\% (10 prohnoziv shchodo rozvytku molochnoho rynku vid ekspertiv Eurotier).

3. Growth of the "vegetable milk" sector. There is evidence that the segment of production of plant analogues of milk, as well as so-called milk without the participation of cows or organic milk will grow and put pressure on the sector. The influence of this trend is already noticeable in developed countries, such as the United States, in particular in California, where many young people have abandoned the classic dairy products. Manufacturers and the processing industry will have to work harder on consumer preferences and develop relevant products. In particular, we are talking about products with additional benefits for the body, enriched with vitamins and trace elements (10 prohnoziv shchodo rozvytku molochnoho rynku vid ekspertiv Eurotier).

Thus, a serious challenge to producers of traditional dairy products is the spread of fashionable trends in healthy eating. How the participants of the dairy market will be able to adapt to changing working conditions and open new horizons, especially in export destinations, will depend on the dynamics of further development of this industry (Vid kilkosti do yakosti: analiz rynku molochnoi produktsii v Ukraini).

Dairy products are raw materials that spoil quickly, so they need to be processed and delivered to the consumer quickly. Companies should strive not only to produce competitive products in price and quality, but also to make effective methods to promote these products. First of all, you need to make the product recognizable. Then it is necessary to ensure that consumers feel the benefits of the product and develop a positive attitude towards the product, emphasizing its strengths. The developed sense of superiority must be translated into the belief in the need to buy, and then form a sense of loyalty.

To maintain a positive consumer response, it is necessary to create a communication message. It is necessary to determine the ways of transmitting the message in terms of the logic of the appeal, the structure and form of the message in terms of its implementation. When determining the message format, you need to choose the right message title, content, illustrations and their design (font, color, etc.). The principles of rationality, morality and emotionality can be the basis of such a message. The choice of the basic principle is based on the target audience and the nature of the product.

Traditional tool for the promotion of dairy products having a special place in this market is branding, which belongs to both the product policy of the enterprise and the communications 
system. The choice of promotion methods depends on the size of the markets. If the market is local, promotion can be limited to local media, in the national market - in addition to national media, a brand should be necessarily well known for effective promotion.

The price of the product plays an important role in the consumer's choice. Sometimes, a low price can repel the consumer, which will indicate poor product quality. It is important to set an average price and provide possible discounts.

Modern methods of product promotion include: the Internet (social media is currently one of the most effective means of promoting goods), specialized exhibitions, franchising. However, not all of them are effective for small dairy producers. Merchandising and tasting become the most desirable tools.

\section{Findings}

For effective promotion of dairy products we can offer:

1. To change the product packaging. An important aspect for brand recognition is the color of the brand. An uncertain color change can lead to a negative attitude towards the brand on the part of consumers.

One of the easiest ways to place product information is to place product information on the packaging. You should carefully choose the text font. For branded products, it is extremely important to place information on the packaging that is synchronized with the brand and that confirms the natural composition and high quality of the product and its usefulness.

2. To conduct promotions, tastings to form the right attitude and memories of the product. Promotions allow you to promote products, while pursuing the following goals: informing potential consumers about the emergence or modification of a product or service; persuasion of the buyer to buy this product, instead of competition; motivating the consumer to buy. For products with wellknown brands, such promotions should rather be an exception, and not include price discounts, as this would be contrary to the high quality of products in terms of consumer psychology. With the help of tastings you can also increase loyalty to the product.

3. It is not necessary to lower the price of a branded product, because it can change the image in the minds of consumers in a negative way.
4. Providing the consumer with information about the possibility of a refund as a guarantee of product quality.

The main aspects that affect the dairy market include:

- supply of raw materials (including capacity for the production of raw materials, setting prices for products, quality parameters, the formation of stable supply channels, etc.);

- availability and use of facilities for processing raw materials;

- the volume of production, its range and distribution among the main market participants;

- determining the proportions of production and consumption of milk and products of its processing.

When promoting dairy products on the consumer market, it is advisable to follow a certain step-bystep scheme:

- dairy market research;

- definition of the target segment of consumers;

- creation of a portrait of the consumer;

- conducting an advertising campaign (advertising on television, outdoor advertising, advertising on transport, SMM-promotion);

$-\mathrm{PR}$;

- sales promotion measures (consumer incentives, incentives for own sales staff, incentives for trade intermediaries).

\section{Conclusions}

A brand is not just a means of differentiating a product from a similar one, it is one of the effective tools to increase the efficiency of the technical level of production, bringing its technology to the current level, a means of significantly improving the quality of products and, ultimately, a means of increasing competitiveness. Branding occupies a special place among the components of the marketing complex, as being initially a component of marketing product policy, also performs a secondary but very important function in the communications system, actively influences the formation of pricing and distribution policy. Branding helps the consumer to decide on the products he or she needs. Consumers choose a brand that has a high value, as it is easier for them to understand the benefits of the product, which at the same time forms the consumer's loyalty to the brand.

Among the main trends in the dairy market there are the main: the trend towardsa transition to healthy 
and quality food; popularity of products without preservatives; increasing demand for lactosefree products, the presence of which stimulates sales of dairy products; growth of the segment of production of plant analogues of milk (biomilk). The impact of this trend is already noticeable in developed countries, where many young people are abandoning classic dairy products.
Based on the research, a scheme for promoting dairy products has been developed, the use of which will allow dairy producers to increase sales, as the proposed algorithm includes: market research, study of customer behavior, as well as the development of an effective advertising campaign. Methods of effective promotion of dairy products on the market are offered.

\section{References:}

Rays, L. (2003). 22 zakona postroeniya brenda [22 laws of brand building]. Moskow: "AST Publishing House".

Shcho take brend i brendynh [What is a brand and branding]. Available at: http://consulting-ua.com/ scho-take-brend-i-brendynh/ (accessed 10 October 2020).

Pertsiya, V., \& Mamleeva, L. (2007). Anatomiya brenda [Brand anatomy]. Sankt-Peterburg: Vershyna.

Nahorniak, T. (2008). Country as a brand. National brand "Ukraine". Strategic Priorities, vol. 4(9), pp. 220-226.

Malinka, A. (2006). "DNA" of the brand as a system of conservation, reproduction and transmission of information to the consumer. Marketing in Ukraine, vol. 1, pp. 34-38.

Wheeler, A. (2004). Individuality of brand. Guide to Creating, promotion and support of strong brands. Moscow: Alpina Business Books.

Shamanska, O., Savetin, V., \& Marchuk, Yu. (2013). Branding as marketing direction of the company. Available at: http://www.economy.nayka.com.ua (accessed 10 October 2020).

Zvarevich, E. (2012). Prodvizhenie molochnoy produktsii [Promotion of dairy products]. Available at: http://www.dairynews.ru/processing/prodvizhenie-molochnoy-produktsii.html (accessed 10 October 2020).

Demchuk, O. M. (2016). Efektyvnist pererobky ta realizatsii moloka v ahrarnykh pidpryiemstvakh [Efficiency of milk processing and sale in agricultural enterprises]. (PhD Thesis), Dnipro: Dnipropetrovsk State Agrarian and Economic University.

10 prohnoziv shchodo rozvytku molochnoho rynku vid ekspertiv Eurotier [10 forecasts for the development of the dairy market from Eurotier experts]. Available at: http://milkua.info/uk/post/10prognoziv-sodo-rozvitku-molocnogo-rinku-vid-ekspertiv-eurotier-2018 (accessed 15 October 2020).

Vid kilkosti do yakosti: analiz rynku molochnoi produktsii v Ukraini [From quantity to quality: analysis of the dairy market in Ukraine]. Available at: https://pro-consulting.ua/ua/pressroom/ot-kolichestva-kkachestvu-analiz-rynka-molochnoj-produkcii-v-ukraine (accessed 15 October 2020). 